\title{
REKAYASA PERANGKAT LUNAK SEBAGAI SYARAT-SYARAT IZIN MENDIRIKAN BANGUNAN DINAS PENANAMAN MODAL DAN PELAYANAN TERPADU SATU PINTU ( DPMPTSP ) KUDUS DENGAN METODE V
}

\author{
Heru Saputro ${ }^{1}$, Esti Wijayanti ${ }^{2}$ \\ ${ }^{1}$ Sistem Informasi, Universitas Islam Nahdlatul Ulama Jepara \\ ${ }^{2}$ Teknik Informatika, Universitas Muria Kudus \\ Email: ${ }^{1}$ herusaputro@unisnu.ac.id, ${ }^{2}$ esti.wijayanti@umk.ac.id
}

(Naskah masuk: 9 Juni 2020, diterima untuk diterbitkan: 20 Juni 2020)

\begin{abstract}
Abstrak
Pada Dinas Penanaman Modal Dan Pelayanan Terpadu Satu Pintu ( DPMPTSP ), Dinas ini mempunyai tugas merumuskan dan melaksanakan kebijakan di bidang penanaman modal serta penyelenggaraan pelayanan administrasi penanaman modal, perizinan dan non perizinan secara terpadu dengan prinsip koordinasi, integritas, sinkronisasi, simplifikasi, keamanan, kepastian dan transparansi. melayani atau memandu seseorang bagaimana cara untuk membuat sebuah perizinan baik dalam hal berusaha atau dalam pembangunan. Sistem yang digunakan untuk membuat perizinan adalah online, Namun dalam hal tersebut masih banyak yang belum paham soal syarat-syarat yang harus dilengkapi untuk membuat izin tersebut, Kesimpulannya adalah membuat aplikasi atau perangkat lunak untuk membantu supaya lebih mudah. maka dari itu disarankan untuk membuat system informasi yang didalamnya terdapat halaman yang berisi syarat-syarat lengkap perizinan, sehingga sebelum melakukan izin seseorang bisa paham apa saja syarat yang harus dilengkapi.
\end{abstract}

Kata kunci: Aplikasi, model v, perijinan bangunan kabupaten kudus

\section{SOFTWARE ENGINEERING AS CONDITIONS FOR CONSTRUCTION OF LICENSING ESTABLISHMENT OF CAPITAL INVESTMENT AND INTEGRATED SERVICE ONE (DPMPTSP) SERVICES WITH METHOD V}

\begin{abstract}
At the One-Stop Investment and Integrated Services Office (DPMPTSP), this office has the task of formulating and implementing policies in the field of investment as well as the administration of investment, licensing and non-licensing administrative services in an integrated manner with the principles of coordination, integrity, synchronization, synchronization, security, certainty and transparency. serving or guiding someone on how to make a permit both in business and in development. The system used to make permits is online, but in that case there are still many who do not understand the conditions that must be completed to make the permit. The conclusion is to make an application or software to help make it easier. therefore it is advisable to create an information system in which there is a page that contains the complete conditions for licensing, so that before doing permission someone can understand what conditions must be completed.
\end{abstract}

Keywords: Applications, model v, Kudus district building permits

\section{PENDAHULUAN}

Dinas kabupaten merupakan salah satu instansi pemerintah yang melayani masyarakat tigkat kabupaten, di antara banyaknya dinas yang ada, dinas penanaman modal dan pelayanan terpadu adalah salah satu dinas penting yang mengurus tentang perizinan usaha dan pembangunan di tingkat kabupaten.

Dinas penanaman modal dan pelayanan terpadu satu pintu di kudus merupakan salah satu instansi pemerintah di kabupaten kudus untuk melayani perizinan pembangunan di kudus, perizinan bangunan yang dilakukan secara online sudah diterapkan di kabupaten kudus dengan melalui webset SIPTO yang bisa di akses dimana saja di kabupaten kudus, dengan menggunakan ini diharapkan orang-orang bisa lebih mudah membuat izin bangunan yang akan dibuat. Namun kendala yang ada adalah masih banyak orang yang tidak tau apa saja syarat yang harus dilengkapi dalam 
mendirikan izin bangunan dan kendala bagaimana cara menggunakan website tersebut, maka dari itu disarankan membuat aplikasi tentang system informasi syarat-syarat mendirikan bangunan. Kesimpulannya adalah memberikan informasi berupa syarat izin dan cara membuat izin, supaya orang tau syarat-syarat apa saja dan bagaimana cara untuk membuat izin mendirikan bangunan secara online di kabupaten kudus.

Pada Dinas Penanaman Modal dan Pelayanan Terpadu Satu Pintu Kudus adalah pembuatan Website Sebagai sistem informasi di Kabupaten Kudus yang menyangkut hal berikut:

1. Informasi tentang pembuatan IMB ( Izin Mendirikan Bangunan ) di kabupaten kudus.

2. Informasi tentang data yang di perlukan dalam pembuatan izin di kabupaten kudus.

Adapun struktur organisasi pada Dinas Penanaman Modal dan Pelayanan Terpadu Satu Pintu Kudus dapat dilihat pada gambar 1

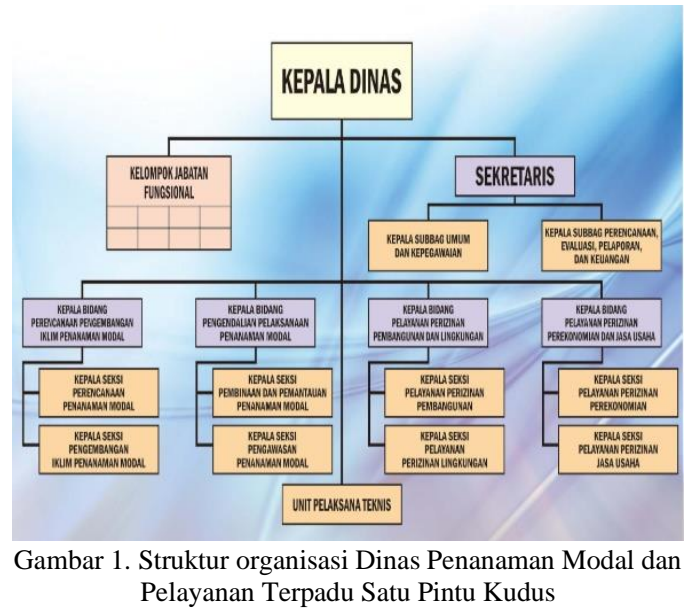

\section{METODOLOGI PENELITIAN}

Adapun metode yang dilaksanakan pada Dinas Penanaman Modal dan Pelayanan Terpadu Satu Pintu Kudus ini dapat dilihat pada Gambar 2:

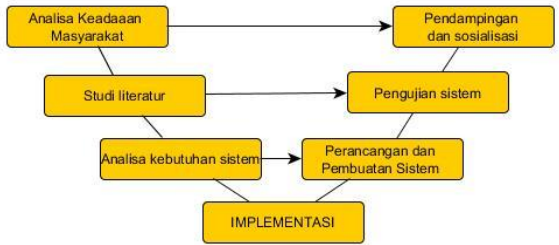

Gambar 2. Metode V penerapan aplikasi Dinas Penanaman Modal dan Pelayanan Terpadu Satu Pintu Kudus

1. Analisa Keadaaan Masyarakat.

Sistem yang digunakan untuk membuat perizinan adalah online, Namun dalam hal tersebut masih banyak yang belum paham soal syarat-syarat yang harus dilengkapi untuk membuat izin tersebut maka dibuatlah penerapan aplikasi Dinas Penanaman Modal dan Pelayanan Terpadu Satu Pintu Kudus

\section{Studi literatur}

Untuk memperkuat ide yang sudah ada maka kami melakukan studi literature dari buku-buku, artikel-artikel baik dari internet maupun jurnal ilmiah serta data-data perpustakaan, dan Anggota.

3. Analisa kebutuhan sistem

Berdasarkan dari hasil observasi tersebut kegiatan pendaftaran anggota yang selama ini terjadi masih dilakukan penerapan aplikasi Dinas Penanaman Modal dan Pelayanan Terpadu Satu Pintu Kudus Maka dari itu harus diterapkan sebuah sistem informasi yang dapat memudahkan proses pendaftaran dengan aplikasi.

4. Perancangan dan Pembuatan Sistem

Perancangan pembuatan sistem mengunakan data flow of diagram untuk mempermudah pembuatan penerapan aplikasi Dinas Penanaman Modal dan Pelayanan Terpadu Satu Pintu Kudus

5. Pengujian sistem

Pengujian yang gunakan untuk mengimplemntasikan perangkat lunak adalah dengan memastikan bahwa kinerja masing-masing sistem dari hasil pembuatan perangkat keras maupun perangkat lunak dapat berfungsi sesuai dengan yang diharapkan.

6. Pendampingan dan sosialisasi

Kami melakukan pengujian, pendampingan serta sosialisasi kepada penguna sistem atau admin sehingga dapat menggunakan dan memaksimalkan sistem tersebut.

\section{HASIL DAN PEMBAHASAN}

\subsection{Analisa}

Sebelum melakukan analisa sistem, terlebih dahulu dilakukan pengumpulan data-data yang ada di dpmptsp kudus apa saja yang harus di analisa dan masalah apa saja yang ada untuk bisa di perbaiki. Pengumpulan data yang dilakukan dengan cara melakukan pendataan langsung dengan mempelajari dan meneliti data-data atau dengan menganalisa aplikasi yang sudah ada di dpmptsp kudus.

\subsection{Perancangan Sistem}

\subsubsection{Flowchart}

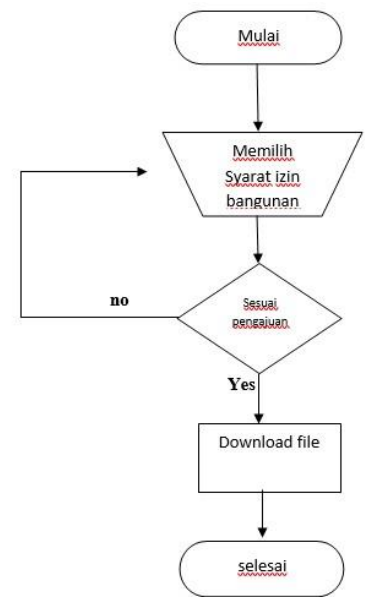

Gambar 3 Flowchart pada aplikasi Dinas Penanaman Modal dan Pelayanan Terpadu Satu Pintu Kudus 


\subsubsection{Database}

Tabel yang digunakan untuk tempat penyimpanan file download. Gambar ERD ini bisa dilihat pada gambar 4.

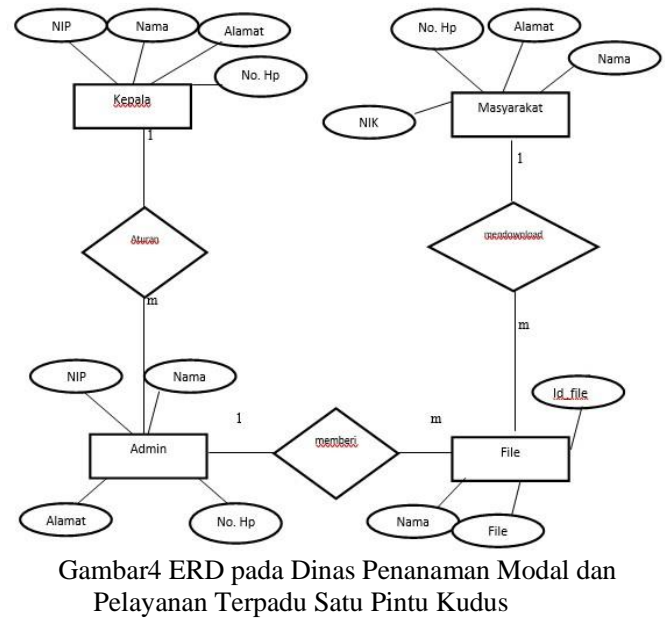

\subsection{Tampilan Sistem}

\subsubsection{Tampilan halaman pemilihan izin}

Pada halaman ini memiliki menu untuk memilih izin apa yang ingin dilihat untuk pemenuhan syaratsyaratnya. Dapat dilihat pada gambar 5 dibawah ini :

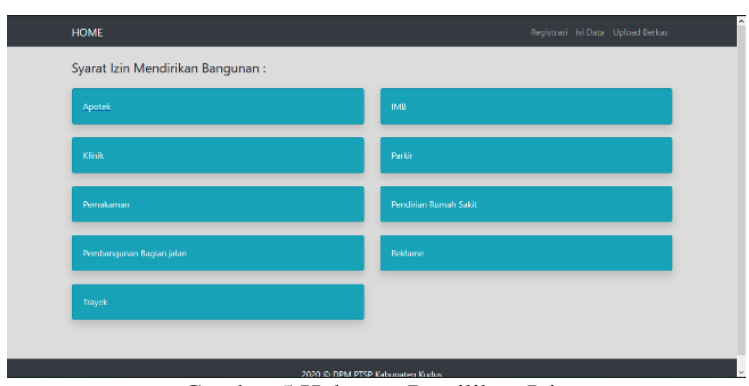

Gambar 5 Halaman Pemilihan Izin

\subsubsection{Tampilan Halaman Daftar Syarat Izin}

Pada halaman ini terdapat syarat-syarat untuk pemenuhan membuat izin mendirikan bangunan. Dapat dilihat pada gambar 6 di bawah ini :

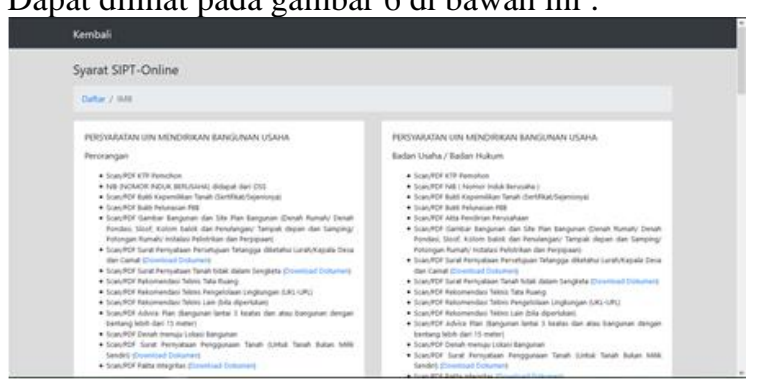

Gambar 6 Tampilan Halaman Dafrat Syarat Izin

\subsubsection{Tampilan Halaman Langkah-langkah Membuat Izin}

Pada halaman ini memberikan sebuah cara / langkah-langkah untuk membuat izin yang ada pada halaman web dpmptsp kudus. Dapat dilihat pada gambar 7 di bawah ini :

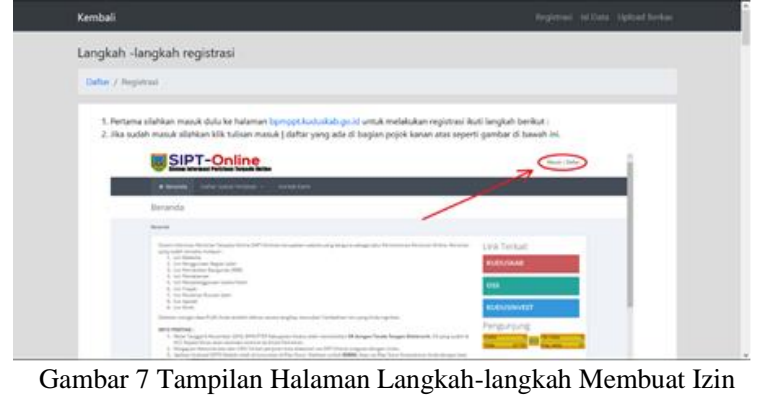

\section{KESIMPULAN}

Dengan demikian dari perancangan system yang dibuat, dapat diambil beberapa kesimpulan, diantaranya :

1. Masyarakat bisa tau apa saja syarat yang harus dipenuhi dalam membuat izin mendirikan bangunan yang akan di buat di kudus.

2. Meringankan pekerjaan supaya orang tidak bolak-balik ke kantor dinas hanya untuk menanyakan syarat yang di butuhkan.

3. Membantu bagaimana membuat izin secara online lewat webset local dpmptsp kudus.

\section{DAFTAR PUSTAKA}

Al Fatta, Hanif 2013, Analisis \& Perancangan Sistem Informasi,Andi Offset, Jakarta.

Fitrani, L., 2015, perancangan aplikasi perangkat lunak perbendaharaan buku perpustakaan (studi kasus di pengadilan negeri garut), jurnal sttgarut, vol.12.

Kurniawan, Erick., Cepat Mahir Visual Basic 2010, Penerbit ANDI, Yogyakarta, 2011.

Kurniawan, Erick., PAS Microsoft Visual Basic 2010, Wahana Komputer, Semarang, 2011.

Hartono , Jogianto, Analisis dan Desain Sistem Informasi : Pendekatan Terstruktur Teori dan Praktek Aplikasi Bisnis, Edisi 2. Cetakan 1. Andi Offsett:Yogyakarta,1999

Kendall, K. E., Kendall, J. E., 2011, systems analysis and design (8th ed). Prentice Hall, One Lake Street, Upper Saddle River, New Jersey 07458.

Martin Fowler, Panduan Singkat Pemodalan Objek Standar, Jogyakarta: Andi, 2005.

Rahardian, D., 2014, perangkat lunak peminjaman dan pengembalian buku di perpustakaan dan arsip daerah kota bandung, Jurnal LPKIA, Vol.1.

Roger S Pressman, Rekayasa Perngkat Lunak Pendekatan Praktisi, Yogyakarta: Andi Offset, 2010.

Rahgu. Gehrke Johannes Ramakhisnan, Sistem Management Database, Yogyakarta: Andi Offset, 2007.

Sutanta, Edhy., Basis Data dalam Tinjauan Konseptual, Penerbit ANDI, Yogyakarta, 2011

Sutabri, Tata 2012, Analisis Sistem Informasi, Andi Offset, Yogyakarta. 
36 Indonesian Journal of Technology, Informatics and Science (IJTIS), Vol. 1, No. 2, Juni 2020, hlm. 33-36

Utami, Ema., RDBMS Menggunakan MS SQL Server 2000, Graha Ilmu, Yogyakarta, 2008

Wijayanti, Esti, Farikhin, Gernowo, 2016. MetodeSerqual rule base Asean University network untukpenilaiankualitas program studi.Tesis, Program Pasca Sarjana Sistem Informasi, Universitas Diponegoro, Semarang.

Wijayanti, Esti. 2018, Model V Untuk Perangkat Lunak Management Pendaftaran Anggota Di Perpustakaan Daerah Kabupaten Kudus. Jurnal disprotek, Jepara.

Wijayanti, Esti. Evanita, ]2018, Rapid Application Development Model used Social Media Content Marketing in the Growth of National for Masyarakat Ekonomi ASEAN (MEA), Internasional Juornal Computer of Aplication

Yates C., 2015, Exploring variation in the ways of experiencing health information literacy: A phenomenographic study, Library \& Information Science Research, 37, 220-227. 